Ritrýnd grein birt 30. maí 2019

\title{
Teymisvinna og forysta: Birtingarmynd fimm árum eftir að innleiðingarferli faglegs lærdómssamfélags lauk
}

\author{
Birna María B. Svanbjörnsdóttir
}

\begin{abstract}
- Abstract
- Um höfundinn

About the author

- Heimildir

Frá ágúst 2009 til desember 2012 átti sér stað vinna við innleiðingu og próun faglegs lærdómssamfélags í nýjum grunnskóla í péttbýli. Samhliða var gerð starfendarannsókn í skólanum, í samstarfi ytri aðila og skólastjórnenda. Par var rannsakað hvaða pýðingu forysta stjórnenda hafði fyrir próun starfshátta í nýjum skóla og hvað studdi hana. Stuðst var við ígrundun stjórnenda, vettvangsathuganir, viðtöl og mat ásamt rýni í fyrirliggjandi gögn í skólanum. Í lok rannsóknartímabilsins sýndu niðurstöður að teymisvinna var einkennandi fyrir skólastarfið og kennarar í teymum tóku forystu á ýmsan hátt með stjórnendum. Mörg teymi mátti skilgreina sem lærdómsteymi. Starfið var ekki átakalaust en stjórnendur sinntu forystuhlutverki sínu með seiglu, eftirfylgni og lausnaleit að vopni. Fimm árum síðar, skólaárið 2017-2018, var gerð eftirfylgnirannsókn í skólanum par sem tekin voru rýnihópaviðtöl við teymi og lagt fyrir matstæki um lærdómssamfélag. Leitað var svara við rannsóknarspurningunum: Hvað einkennir teymisvinnu og forystu stjórnenda og kennara/teyma í skólanum fimm árum eftir að innleiðingarferli lærdómssamfélags lauk árið 2012? Hverjar eru helstu áskoranirnar? Frá pví að fyrri rannsókn lauk hefur nemendum skólans fjölgað og miklar breytingar hafa orðið í starfsmannahópnum, ekki síst stjórnendateyminu. Enn er teymisvinna við lýði í skólanum og innri umgjörð skólans styður við samkennslu árganga, samstarf og leiðsögn. Skilgreining og stigskipting teyma sem stuðst var við í upphafi er pó ekki öllum kunn, vinnubrögð í teymum eru ekki samræmd og kennarar í teymum sinna forystu lítið. Sterkar vísbendingar eru um að teymi séu einangruð og að skólastjórnendur fylgist minna með kennslu og námi í kennslustundum en áður. Hér verður greint frá helstu niðurstöðum eftirfylgnirannsóknarinnar og pær skoðaðar í samhengi við fyrri niðurstöður.
\end{abstract}

Efnisorð: Faglegt lærdómssamfélag, teymisvinna, samstarf, leiðsögn og forysta.

\section{Inngangur}

Hugtakið lærdómssamfélag er nokkuð vel pekkt í íslenskri skólamálaumræðu og hér er gengið út frá pví að lærdómssamfélag í skóla (e. professional learning community) sé menning sem styðji við faglega starfshætti og styrki innviði skólakerfis. Slík menning einkennist meðal annars af samstarfi, leiðsögn og skuldbindingu (Fullan og Hargreaves, 2016) og getur stuðlað að og viðhaldið námi allra í skólanum, aukið gæði kennslunnar og bætt árangur nemenda (DuFour og Fullan, 2013; Vescio, Ross og Adams, 2008). Gæði kennslunnar og virk forysta eru peir pæettir í skólastarfi sem hafa mest bein og óbein áhrif á námsárangur nemenda en peir haldast 1 hendur við faglega starfshætti og starfspróun kennara (Fullan og Hargreaves, 2016; Seashore 
Louis, Leithwood, Wahlstrom og Anderson, 2010). Kennarastarfið er margbreytilegt og flókið og rannsóknir sýna að veita parf nýliðum og öðrum kennurum faglega og formlega leiðsögn og stuðning til að peir nái tökum á starfinu, próist í pví og tileinki sér ný vinnubrögð (Börkur Hansen og Steinunn Helga Lárusdóttir, 2014; María Steingrímsdóttir og Guðmundur Engilbertsson, 2018).

Áhersla á að innleiða starfshætti lærdómssamfélags í íslenskum skólum til að tryggja umbætur í skólastarfinu hefur aukist á undanförnum árum. Рað kemur meðal annars fram í Hvítbók um umbatur í menntun (Mennta- og menningarmálaráđuneytið, 2014), í skýrslu Fagráđs um símenntun og starfspróun kennara (2016) og í tillögum stýrihóps um Menntun fyrir alla á Íslandi (2017).

Á Skólapingi sveitarfélaga í nóvember 2017 kom meðal annars fram að pað væri grundvallaratriði að styrkja starfið inni í skólunum með starfspróun, símenntun og stuðningi, og byggja upp faglegt lærdómssamfélag sem grundvallaðist á samstarfi og teymisvinnu (Svandís Ingimundardóttir og Valgerður Ágústsdóttir, 2018).

Dessir pættir voru hafðir til hliðsjónar hjá starfshópi sem fékk pað hlutverk árið 2006 að hanna nýjan og framsækinn grunnskóla í péttbýli. Meginniðurstöður hópsins voru að lögð yrði áhersla á nám allra í skólanum, jafnt nemenda sem starfsfólks. Lagt var til að starfshættirnir skyldu einkennast af samstarfi, víðsýni og virðingu par sem komið væri til móts við mismunandi parfir einstaklinga. Markmiðið var að byggja upp og próa lærdómssamfélag með áherslu á teymisvinnu ${ }^{1}$ og forystu til náms (Birna Svanbjörnsdóttir, 2015). Skólinn tók til starfa árið 2009 en skólastjóri var ráđinn til skólans ári fyrr (Birna Svanbjörnsdóttir, Allyson Macdonald og Guðmundur Heiðar Frímannsson, 2010). Greinarhöfundur vann starfendarannsókn í samstarfi við skólastjórnendur fyrsta prjú og hálft árið, 2009-2012. Hann fylgdist með starfi stjórnenda og mat próun og árangur lærdómssamfélagsins með matstæki, viðtölum, vettvangsathugunum og rýni í fyrirliggjandi gögn. Til viðmiðunar um gæði og próun teymisvinnunnar var stuðst við stigskiptingu KrøllSchwartz (2004). Samkvæmt henni einkennist skilvirkasta tegund teymisvinnu af langvarandi og skuldbindandi samvinnumenningu, viðleitni til að nýta styrkleika hvers og eins og stuðla að faglegu og persónulegu námsferli (sjá töflu 1).

Rannsóknin náði til allra aðila innan skólans, pað er stjórnenda, kennara, nemenda, stuðningsfulltrúa, skólaliða og foreldra. Stjórnendur rýndu í starfið og ígrunduðu pað. Einnig skoðaði hann niðurstöður samræmdra próf og Skólapúlsins.

Раð sem einkenndi starfið og starfsumhverfið á rannsóknartímabilinu og í lok pess árið 2012, var að:

- stjórnendateymið var eins samsett allan tímann,

- hagnýt og fagleg vinna í teymum var tímafrek og eyddi mikilli orku. Margir upplifðu hana sem aukið vinnuálag,

- átök voru milli ríkjandi hefða í skólastarfi almennt og faglegrar viðleitni til breytinga innan skólans,

- kennarar voru jákvæðir en kölluðu eftir leiðsögn við teymisvinnuna í kennslu,

- áhersla á umgjörð teymisvinnunnar óx og studdi við faglegt starf í teymunum,

- teymisvinna varð einkenni skólans. Haldnir voru prír teymisfundir á viku, einn um kennsluáætlanir, einn um nemendamál og einn um trúnaðarmál kennara,

- teymin tóku forystu um mál innan skólans (Birna Svanbjörnsdóttir, 2015; Birna Svanbjörnsdóttir, Allyson Macdonald og Guðmundur Heiðar Frímannsson, 2016).

Degar rannsóknartímabilinu lauk í lok árs 2012 var ákveðið að gerð yrði eftirfylgnirannsókn í skólanum fimm árum síðar í peim tilgangi að sjá hvort og pá hvaða breytingar hefðu orðið á áherslum, vinnubrögðum og gildum á pessum tíma með раð að markmiði að skilja hvernig starfið hafði próast, af hverju og hvaða leiðir mætti fara til að styðja við frekari próun og umbætur. 
Í eftirfylgnirannsókninni skólaárið 2017-2018 var leitað svara við eftirfarandi spurningum:

Hvað einkennir teymisvinnu og forystu í skólanum fimm árum eftir að innleiðingarferli lærdómssamfélags lauk árið 2012? Hverjar eru helstu áskoranirnar?

Í pessari rannsókn, sem og peirri fyrri sem pessi fylgir eftir, er forysta skilgreind sem gagnvirkt framlag mismunandi aðila í skólanum, bæði skólastjórnenda (skólastjóra og deildarstjóra) og kennara, og litið svo á að hún geti orðið til sem afl í samræðum og samstarfi fólks pegar samhugur er um að takast á við mikilvæg verkefni til umbóta fyrir skólastarf (Spillane, 2006). Um er að ræða forystu til náms (e. leadership for learning) par sem nám er gert að meginviðfangsefni skólastarfsins (MacBeath, Swaffield og Frost, 2009). Stjórnendateymi (skólastjóri og deildarstjórar), er ábyrgt fyrir próunarstarfi, kennslu og námi í skólanum og að hvetja, styðja og efla forystu kennara (Birna Svanbjörnsdóttir o.fl., 2016).

Hér verður greint frá fræðilegum bakgrunni eftirfylgnirannsóknarinnar, rannsóknarsniði, niðurstöðum og umræðum. Í lokin eru helstu áskoranir dregnar fram.

Degar fjallað er um stjórnendur í pessari grein er átt við stjórnendateymið nema annað sé tekið fram.

\section{Fræðilegur bakgrunnur}

Hugmyndafræði lærdómssamfélags er nátengd hugmyndum um fagmennsku og starfspróun (Fullan og Hargreaves, 2016) en í ljós hefur komið að kennarar og stjórnendur sem eru skuldbundnir hugmyndafræðinni stuðla að varanlegum breytingum og námi (Hall og Hord, 2011). Fagrád um símenntun og starfspróun kennara (2016) skilgreinir starfspróun sem samfellt meðvitað og mótað ferli sem leiðir til umbóta í faglegu lærdómssamfélagi. Áhersla er lögð á að starfspróunin sé samofin daglegu starfi kennara og hafi skýran tilgang og markmið sem miði að pví að efla færni og pekkingu starfsfólks skóla og auka gæði í starfi.

Í starfsumhverfi lærdómssamfélags ríkir traust par sem fólk vinnur að sameiginlegum markmiðum, hefur tækifæri til ígrundunar, leiðsagnar og endurgjafar og er ábyrgt fyrir árangri (Hargreaves, 2007; Prytula, 2012; Seashore Louis o.fl., 2010). Sameiginlegt nám og samvinna meðal kennara, sem og milli kennara og stjórnenda, getur stutt við fagmennsku og kennslufræðilega færni (Bolam, McMahon, Stoll, Thomas og Wallace, 2005; Roy og Hord, 2006; Seashore Louis o.fl., 2010).

Hugtakið samstarf getur haft mismunandi merkingu. Ef litið er á pað sem pýðingu á enska hugtakinu cooperation felur pað í sér að skipta með sér verkum og ábyrgð til að létta á vinnuálagi og væri réttara að nota hugtakið samrád sem pýðingu á pví. Ef pað er hins vegar pýðing á hugtakinu collaboration snýst pað um sameiginlega ábyrgð, ígrundun og lausnaleit og stuðlar að starfspróun og umbreytingu í starfi í anda hugmyndafræði lærdómssamfélags (Jackson og Burch, 2016). Til að efla lærdómssamfélag í skólum er mikilvægt að tryggja tækifæri til samvinnu og náms á starfsvettvangi (Anna Kristín Sigurðardóttir, 2010; Darling-Hammond og Richardson, 2009).

Áherslumunur getur verið um skilgreiningu á lærdómssamfélagi en hér er miðað við að eftirfarandi pættir einkenni lærdómssamfélag:

- áhersla á nám nemenda,

- sameiginleg sýn, gildi og væntingar,

- markmiðs- og árangursmiðað starf,

- sameiginleg greining á stöðu og árangri,

- forysta og skuldbinding til að leggja sitt af mörkum til stöðugrar próunar,

- starfspróun. 
(DuFour og Fullan, 2013; Hargreaves og Fullan, 2012; Huffman og Hipp, 2003; Olivier og Hipp, 2010; Roy og Hord, 2006).

Í nýlegum gögnum um starfsaðstæður íslenskra kennara kemur fram að peir upplifa mikið vinnuálag í starfi, sem að einhverju leyti tengist kjaramálaumræðu og menntastefnu um menntun fyrir alla, og skort á stuðningi til starfspróunar (Birna Sigurjónsdóttir, 2017; Nýliðun og bætt starfsumhverfi grunnskólakennara, 2017; Svandís Ingimundardóttir og Valgerður Ágústsdóttir, 2018). Drátt fyrir að rannsóknir sýni mikilvægi starfshátta lærdómssamfélags virðast kennarar almennt styðja hver annan lítið í starfi og veita hver öðrum litla endurgjöf (e. feedback) (Doppenberg, Brok og Bakx, 2012). Niðurstöður Teaching and Learning International Survey (TALIS, 2013) gefa til kynna að íslenskir kennarar styðji síður hver annan og telji sig fá minni endurgjöf frá samkennurum en kennarar í öđrum TALIS-löndum (Ragnar Ólafsson, Allyson Macdonald og Auður Pálsdóttir, 2012). Hið sama á við pegar kemur að leiðsögn við nýliða en sýnt hefur verið fram á að formleg og faglega útfærð leiðsögn til nýliða stuðlar að aukinni starfsánægju og starfspróun sem getur viðhaldið jafnvægi í stéttinni og komið í veg fyrir brotthvarf (Ingersoll, 2012). Leiðsögnin felur í sér gagnvirkar samræður um starfið og mismunandi útfærslur pess út frá rýni í pað, ígrundun og skilvirkri endurgjöf. Leiðsögn getur átt sér stað í samstarfshópi aðila með mismunandi starfsreynslu sem leitar í sameiningu leiða til að bæta og próa fagmennsku sína og skólastarf (Heikkinen, Jokinen og Tynjälä, 2012). Aðrir kennarar purfa einnig leiðsögn við próun náms og kennslu með markvissum og kerfisbundnum hætti, til dæmis í framhaldi af heimsóknum í kennslustundir, og er pað hlutverk skólastjóra og annarra sem taka forystu í skólanum að sinna henni (Börkur Hansen og Steinunn Helga Lárusdóttir, 2014; María Steingrímsdóttir, Eygló Björnsdóttir og Gretar L. Marinósson, 2017; Ragnhildur Bjarnadóttir, 2015).

Í rannsókn um mat og gagnsemi leiðsagnar hjá 239 nýliðum í íslenskum grunnskólum og framhaldsskólum kemur fram að skortur er á formlegri leiðsögn til nýliða í starfi í íslenskum skólum og að óformleg leiðsögn veitir ekki nægilegan stuðning. Að mati kennara er gagnlegast að sá sem veitir leiðsögnina hafi pekkingu á leiðsagnarhlutverkinu, eins að hann hafi svipaðan bakgrunn og peir og fundi með peim reglulega og markvisst (María Steingrímsdóttir og Guðmundur Engilbertsson, 2018). Svipaðar niðurstöður er að finna í rannsókn á nýliðum í framhaldsskóla en í peirri rannsókn voru kennarar pó enn afdráttarlausari um mikilvægi pess að leiðsagaraðili hefði svipaðan bakgrunn og peir (Hildur Hauksdóttir, María Steingrímsdóttir og Birna Svanbjörnsdóttir, 2018). Leiðtogum við innleiðingu og próun Byrjendalæsis er ætlað að fara í vettvangsheimsóknir til kennara í kennslu mánaðarlega og eiga í kjölfarið samræður um kennsluna. Niðurstöður rannsóknar á innleiðingu Byrjendalæsis sýndu að rúmur helmingur leiðtoga framfylgdi pessum viðmiðum en tæpur priðjungur fór sjaldnar en mánaðarlega í slíkar heimsóknir (María Steingrímsdóttir o.fl., 2017).

Vaxandi áhugi er á teymiskennslu međal kennara og stjórnenda í íslenskum skólum með áherslu á sameiginlega ábyrgð og aukna samvinnu í opnum rýmum. Kennarar í skólum sem skipulagðir eru sem teymiskennsluskólar eru ánægðari í starfi, eiga opnari og gagnrýnni umræðu um skólamál og eru jákvæðari gagnvart próunarstarfi en kennarar í öđrum skólum (Gerður G. Óskarsdóttir, 2014).

Markmiðsstýrð teymisvinna og teymiskennsla getur nýst sem tæki til að byggja upp vettvang til að deila hugmyndum og leiðum í kennslu, og til skapandi og gagnrýninnar hugsunar og ígrundunar (Krøll-Schwartz, 2004). Teymi eru grunneining í lærdómssamfélagi og gegna pví hlutverki að rækta samvinnu, faglega samstöðu, traust og skuldbindingu. Dau geta ýtt undir nám á starfsvettvangi og stuðlað að dýpri skilningi starfsfólks á eigin námi og leiðum í námi. Pannig geta teymi stutt við starfspróun teymisaðila ef pað er haft að markmiði (Anna Kristín Sigurðardóttir, 2010; Prytula, 2012). Útfæra má teymiskennslu á mismunandi hátt hvort heldur sem er í aldursskiptum eða aldursblönduðum námshópum. Aldursblöndun er talin hafi ýmsa kosti í för með sér. Hún getur bæði verið félagslega örvandi og námslega árangursrík fyrir nemendur hvort heldur sem er í fámennum eða fjölmennum skólum. Með samkennslu gefst nemendum 
tækifæri til að tengjast og læra hver af öðrum en einnig getur sú áskorun sem henni fylgir stuðlað að fjölbreyttum kennsluháttum kennara (Åheim, 2009).

Skilgreina má teymisvinnu í mismunandi stigum par sem stig eitt er einfaldast og stig fjögur er flóknast og skilvirkast. Stig eitt er skilgreint sem samráð eða samræming (e. cooperation) kennara en par er áherslan á afmarkaða verkpætti og nám nemenda en ekki nám eða starfspróun kennara. Á fjórða stigi er um að ræða samstarf (e. collaboration) og áhersla er á nám allra, pað er nemenda, kennara og teymisins (sjá töflu 1).

Tafla 1. Mismunandi stig teymisvinnu

\begin{tabular}{ll}
\hline Stig & Áherslur \\
\hline Stig 1. Samrád/samræmi & Samhæfing á skilum stærri skriflegra verkefna. \\
kennara & Unnið saman að verkefnum sem ná yfir styttri \\
Unnið með afmarkaða verkpætti, & afmarkaðan tíma. \\
svo sem hvaða verkefni og & Áhersla er á nemendur en ekki á samvinnu og tengsl \\
námsefni á að vinna. & kennara. \\
\end{tabular}

\section{Stig 2. Aukið samráð kennara \\ Unnið með afmarkaða verkpætti og markmið um framvindu nemenda í námi.}

\section{Stig 3. Kennarateymi - samvinnuteymi}

Unnið með afmarkaða verkpætti, markmið um framvindu nemenda og markmið um kennarahlutverkið.

\section{Stig 4. Námsteymi \\ Unnið með afmarkaða verkpætti, markmið um framvindu nemenda í námi, markmið um framvindu kennara og markmið um framvindu teymisins.}

\section{Auk fyrri pátta:}

Unnið saman að stærri faglegum verkefnum fyrir bekkinn.

Menning bekkjarins rædd.

Unnið með ríkjandi kennsluaðferðir og vinnulag.

Sameiginleg viðmið sett um námsmat og unnið saman að námsmati.

Rætt um hæfileika og nám nemenda.

Nemendasamtöl haldin í sameiningu.

\section{Auk fyrri pátta:}

Rætt um nám kennarans (hvernig og hvað hann lærir).

Unnið meðvitað með próun/framvindu kennarahlutverksins.

Unnið með samvinnupátt teymisins. Unnið með menningu teymisins. Áherslan er bæði á vinnu með faglega og persónulega námsframvindu nemenda, samvinnuhefð og innbyrðis tengsl kennara.

\section{Auk fyrri pátta:}

Langvarandi og skuldbindandi samvinna.

Markvisst reynt að styrkja teymið, t.d. með sjálfsígrundun.

Reynt að nýta styrkleika hvers og eins til hins ítrasta. Unnið аð sameiginlegum skilningi innan teymisins.

Áhersla er bæði á að vinna með faglegt og persónulegt námsferli og samvinnumenningu.

(Krøll-Schwartz, 2004)

Forysta hefuráhrifápróun skólastarfs og nám nemenda og gegnir lykilhlutverkiílærdómssamfélagi, einkum með pví móta stefnu, rýna í og styðja við faglega menningu og kennslu auk pess að skapa aðstæður til samstarfs og samstöðu (Hopkins, Stringfield, Harris, Stoll og Mackay, 2014; Leithwood, Anderson, Mascall og Strauss, 2010). Dreifð forysta (e. distributed leadership) getur dregið úr valdaójafnvægi og stuðlað að heildrænni nálgun og sameiginlegri ábyrgð í skólastarfinu en pað fer eftir pví hvernig hún er útfærð hver áhrifin verða (Harris, 2010). Ef forystan dreifist bæði á formlega stjórnendur og pá sem ekki sinna formlegum stjórnendastöðum og felst í 
gagnvirku námi par sem mismunandi aðilar læra saman og hver af öðrum er hún líkleg til að stuðla að frampróun í skólastarfi, mynda sterka heild og samstöðu. Pannig geta kennarar tekið forystu um pætti í skólastarfinu sem peir finna hjá sér skuldbindingu og vilja til að próa (Lambert, 2003; Spillane, 2006).

Kennarar bera pannig, ekki síður en stjórnendur, ábyrgð á pví að taka forystu í peim tilgangi að breyta og próa eigin fagmennsku og skólastarf. Í Ontario í Kanada hefur verið próuð sérstök námsleið, Teacher Learning and Leadership Program (TLLP), par sem reyndum kennurum gefst kostur á stuðningi til starfspróunar sem samofin er starfi á vettvangi. Stuðningurinn tengist vinnu kennara, pörfum peirra og reynslu við kennsluna og einnig pörfum nemenda og hefur skilað góðum árangri (Lieberman, Campbell og Yashkina, 2017).

Niðurstöður starfsháttarannsóknar í íslenskum skólum sýna að forysta um frampróun byggist fremur á samstarfi innan skólans en frumkvæði stjórnenda. Skólastjórar fara lítið inn í kennslustundir til að rannsaka kennslu og nám eða leiðbeina um kennslufræðilega pætti. Deir líta pó á pað sem hlutverk sitt að leiðbeina um nám og kennslu og segjast gera pað með ýmsum hætti. Рað virðist pó einkum vera óformlega og með pví að skapa aðstæður en ekki markvisst og formlega (Börkur Hansen og Steinunn Helga Lárusdóttir, 2014). Svipaðar niðurstöður má sjá í rannsókn um Byrjendalæsi í íslenskum skólum (Sigríður Margrét Sigurðardóttir, María Steingrímsdóttir og Eygló Björnsdóttir, 2017) en par kemur fram að skólastjórar tóku alvarlega pað hlutverk sitt að marka stefnu og fá samstöðu um sameiginlega sýn um að innleiða og próa Byrjendalæsi í skólum sínum en sýndu takmarkaða forystu um að efla kennslu og nám almennt. Kennarar sem tóku að sér að vera leiðtogar í Byrjendalæsi og fengu formlega menntun í samræmi við pað hlutverk, tóku gjarnan forystu og fagmennska peirra jókst. Samvinna peirra jókst einnig og í krafti hennar og aukinnar fagmennsku tóku peir í meira mæli ákvarðanir um að breyta og próa kennsluhætti, leiðbeina öðrum kennurum og fundu fyrir aukinni hlutdeild í skólastarfinu í heild. Í sumum skólum reyndist erfitt að fá kennara til að taka petta hlutverk að sér. Í nokkrum skólum höfðu kennarar sem pó litu ekki á sig sem forystuaðila frumkvæði að pví að innleiða Byrjendalæsi (Sigríður Margrét Sigurðardóttir o.fl., 2017).

Í próunarverkefninu Carpe Vitam sem hafði pað að markmiði að skilja samhengi milli hugtakanna forysta og nám með pátttöku skólastjóra og kennara sjö pjóða árin 2002-2005 gáfu niðurstöður til kynna fimm meginpætti sem einkenndu forystu til náms. Deir voru: Áhersla á nám, aðstæður til náms, samræður, sameiginleg (e. shared) forysta og sameiginlegur skilningur á ábyrgð (MacBeath o.fl., 2009).

Á árunum 2006-2010 var unnin rannsókn og safnað gögnum um breytingastarf í norskum skólum með раð аð markmiði að skilja og lýsa hæfileikum peirra til breytingar, hvernig hún er skipulögð, framkvæmd og próuð í skólum, og hvað pað er sem leiðir hana áfram og styður hana. Litið var til tveggja breyta, p.e. hæfileika til umbreytinga og ytri stuðnings. Niðurstöður sýndu sex mismunandi pætti sem leiddu breytingastarfí skólunum, p.e. ákveðna hugmyndafræði, skipulag, líkan að fyrirmyndastarfi, lausnaleit og teymisvinnu/teymiskennslu. Í ljós kom að teymi í skólum tóku gjarnan forystu en að hætta var á að teymi yrðu of sjálfstæð og einangruðust hvert frá öđru. Í slíkum tilvikum skilaði teymisvinnan ekki tilætluðum árangri (Blossing, Nyen, Söderström og Hagen Tønder, 2015).

Hér á eftir verður greint frá aðferð við eftirfylgnirannsóknina, frá teymunum í skólanum, viðtölum og matstæki, og frá siðferðilegum páttum og takmörkunum.

\section{Аðferð}

Meginmarkmið eftirfylgnirannsóknarinnar sem unnin var í skólanum frá vori 2017 til vors 2018 var að fá innsýn í hvað einkennir lærdómssamfélag, teymisvinnu og forystu í skólanum fimm árum eftir að innleiðingarferli lauk árið 2012 og hverjar væru helstu áskoranirnar, að skilja 
hvernig starfið hafði próast, af hverju og hvaða leiðir mætti fara til að styðja við frekari próun og umbætur.

Til að leita svara við rannsóknarspurningunni og fá sem heildstæðasta mynd af stöðunni var talið mikilvægt að heyra raddir og túlkun stjórnenda og kennara um samstarf peirra, samskipti og áherslur í starfi á vettvangi. Dví varð eigindleg rannsóknaraðferð fyrir valinu (Coe, Waring, Hedges og Arthur, 2017). Gagna var einkum aflað með tvennum hætti. Annars vegar var stuðst við matstæki fyrir lærdómssamfélag (Olivier og Hipp, 2010) og hins vegar við rýnihópaviðtöl til að fá samræður milli aðila í teymum og fá innsýn í hvernig peir upplifa og túlka aðstæður (Coe o.fl., 2017). Sjá má yfirlit yfir gagnaöflun í töflu 2.

Tafla 2. Yfirlit yfir gagnaöflun

8 teymi Matskvarði um lærdómssamfélag (september 2017)

7 Rýnihópaviðtöl (frá maí 2017-mars 2018)

$1 \quad$ Umræðufundur

Tilgangurinn með notkun matskvarðans var einkum að varpa ljósi á hugmyndafræði lærdómssamfélags og kalla fram umræður um hana.

Eftir að hafa fengið sampykki fræðslustjóra og skólastjóra fyrir rannsókninni var leitað til fulltrúa allra teyma í skólanum um pátttöku. Tilgangur og markmið rannsóknarinnar voru kynnt á starfsmannafundi í skólanum í september 2017 og par voru einnig kynntar eða rifjaðar upp og ræddar helstu áherslur og niðurstöður rannsóknarinnar 2009-2012. Veruleg endurnýjum hefur orđið á starfsliði skólans frá pví pá. Á fyrsta starfsári skólans voru kennarar 11 og nemendur 150 en í lok rannsóknartímabilsins 2012 voru kennarar 26 og nemendur 295. Skólaárið 2017-2018 voru kennarar 29 og nemendur 380 (sjá töflu 3).

Hugtakið lærdómssamfélag var mikið notað meðal kennara í skólanum á upphafsárunum og unnið var markvisst að pví að leita sameiginlegs skilnings á merkingu pess. Lögð var áhersla á að próa vinnubrögð eins og ígrundun, leshringi og vettvangsathuganir auk pess að efla faglega forystu sem flestra (Birna Svanbjörnsdóttir, 2015).

Hér verður greint frá umgjörð innra starfs skólans, pátttakendum, matstækjum, úrvinnslu og greiningu gagna ásamt takmörkunum og siðferðilegum páttum.

\section{Umgjörd innra starfs}

Skólinn er skipulagður sem teymisskóli og átta teymi mynda umgjörð um innra starf hans. Рað eru stjórnendateymi, fimm bekkjarteymi, list- og verkgreinateymi og teymi ípróttakennara. Stjórnendateymið er mannað premur fulltrúum; skólastjóra og tveimur deildarstjórum, en önnur teymi eru stærri, með 5-9 fulltrúa hvert (með stuðningsfulltrúum). Í töflu 3 má sjá fjölda kennara í hverju teymi. Í 2.-7. bekk er eitt teymi fyrir tvo árganga. Eitt teymi er fyrir 8., 9. og 10. bekk og eitt teymi fyrir fyrsta bekk. Teymi list- og verkgreina og teymi ípróttakennslu nær yfir alla árganga. Pau teymi vinna náið saman og líta gjarnan á sig sem eitt teymi. Dessi tvö teymi voru saman í rýnihópaviðtalinu en mátu sig hvort í sínu lagi út frá matskvarðanum (tafla 3). Fjöldi barna í hverju bekkjarteymi er frá 40-100. Aldursblöndun hefur verið hluti af stefnu skólans frá upphafi. 
Tafla 3. Teymin í skólanum 2012 og 2017-2018

\begin{tabular}{|c|c|}
\hline 2012 & 2017-2018 \\
\hline 26 kennarar og 295 nemendur & $\begin{array}{l}29 \text { kennarar (par af prír frá upphafsárinu) } \\
\text { og } 380 \text { nemendur }\end{array}$ \\
\hline $\begin{array}{l}\text { - Stjórnendateymi, skólastjóri og } \\
\text { aðstoðarskólastjóri (2) }\end{array}$ & $\begin{array}{l}\text { - Stjórnendateymi; skólastjóri og tveir } \\
\text { deildarstjórar (3) }\end{array}$ \\
\hline - 1. bekkjarteymi & - 1. bekkjarteymi (3) \\
\hline - 2. og 3. bekkjarteymi & - 2. og 3. bekkjarteymi (4) \\
\hline - 4. og 5. bekkjarteymi & - 4. og 5. bekkjarteymi (5) \\
\hline - 6. og 7. bekkjarteymi & - 6. og 7. bekkjarteymi (5) \\
\hline - 8. og 9. bekkjarteymi & - 8., 9. og 10. bekkjarteymi (5) \\
\hline - 10. bekkjarteymi & - List- og verkgreinateymi (4) \\
\hline $\begin{array}{l}\text { - List- og verkgreinateymi og } \\
\text { ípróttakennarateymi }\end{array}$ & - Ípróttakennarateymi (3) \\
\hline
\end{tabular}

Stjórnendur og allir kennarar í teymunum nema einn (forfallaður vegna veikinda), auk tveggja proskapjálfa, tveggja stuðningsfulltrúa og tveggja kennaranema, tóku pátt í rannsókninni, samanlagt 37 aðilar. Til að undirbúa jarðveginn og skoða aðstæður fyrir rannsóknina var tekið rýnihópaviðtal við stjórnendateymið (3 pátttakendur) vorið 2017. Pá var einnig farin skoðunarferð um skólann. Á starfsmannafundinum í september mátu öll teymin sig út frá matstæki um lærdómssamfélag. Í kjölfarið voru tekin sex rýnihópaviðtöl við bekkjarteymi og list-, verk- og ípróttateymið.

\section{Matstæki, úrvinnsla og greining gagna}

Matstækið er samsett af sex áherslupáttum (alls 52 staðhæfingum) sem metnir eru á fjögurra stiga kvarða, p.e. mjög ósammála, ósammála, sammála og mjög sammála. Einnig gefst kostur á að skrá eigin athugasemdir (Olivier og Hipp, 2010). Í töflu 4 er yfirlit um áherslupættina og gefin dæmi um staðhæfingar.

Tafla 4. Áherslupættir og staðhæfingar

\begin{tabular}{ll}
\hline $\begin{array}{l}\text { Áherslupættir og } \\
\text { fjöldi undirliða/ } \\
\text { staðhæfinga }\end{array}$ & Dæmi um staðhæfingar \\
\hline $\begin{array}{l}\text { Dreifð og styðjandi } \\
\text { forysta (11) }\end{array}$ & $\begin{array}{l}\text { Starfsfólk tekur virkan pátt í umræðum og ákvörðunartöku um flest } \\
\text { pau málefni er varða skólann. } \\
\text { Skólastjóri deilir ábyrgð og vekur athygli á nýbreytni í starfi skólans. }\end{array}$ \\
$\begin{array}{l}\text { Sameiginleg gildi og } \\
\text { sýn (9) }\end{array}$ & $\begin{array}{l}\text { Samstarf starfsfólks einkennist af ígrundun, samræðu og samvinnu og } \\
\text { styður við sameiginleg gildi starfsfólks. }\end{array}$ \\
& $\begin{array}{l}\text { Lögð er áhersla á heildstæða sýn á nám nemenda í stað pess að horfa } \\
\text { einungis á niðurstöður kannana eða prófa. }\end{array}$ \\
$\begin{array}{l}\text { Sameiginlegt nám og } \\
\text { starfsprón (10) }\end{array}$ & $\begin{array}{l}\text { Starfsfólk skipuleggur og vinnur saman að pví að leita leiða til að } \\
\text { mæta mismunandi pörfum nemenda. }\end{array}$ \\
Starfsfólk skólans finnur sig skuldbundið til að beita kennsluháttum \\
sem stuðla að námi nemenda. \\
$\begin{array}{l}\text { Miðlun eigin reynslu } \\
\text { til samstarfsfólks (7) }\end{array}$ & $\begin{array}{l}\text { Starfsfólk deilir óformlega með sér hugmyndum og tillögum sem } \\
\text { stuðlað geta að framförum í námi nemenda. }\end{array}$ \\
& $\begin{array}{l}\text { Starfsfólk vinnur saman að endurskoðun á verkefnum og vinnu } \\
\text { nemenda með pað að leiðarljósi að efla eigið starf/kennslu. }\end{array}$
\end{tabular}


Styðjandi aðstæður samskipti (5)

Styðjandi aðstæðurinnra skipulag (10)
Starfsfólk ber umhyggju fyrir nemendum og samskipti í skólanum einkennast af trausti og virðingu.

Í skólanum ríkir traust og virðing sem auðveldar starfsfólki að taka áhættu og prófa nýjungar.

Dagskipulag í skólanum styður við tækifæri starfsfólks til að læra hvert af öðru og saman.

Skólapjónusta og aðrir sérfræðingar styðja við starfspróun og nám starfsfólks.

Í viðtölunum var stuðst við viðtalsramma og var lengd peirra frá 43-58 mínútur. Viðtölin voru hálfstöðluð og spurt var spurninga eins og:

- Hvernig er hugtakið lærdómssamfélag pekkt og notað í skólanum, hvað merkir pað og hver er birtingarmynd pess?

- Hvað einkennir teymisvinnuna?

- Hvaða merkingu hefur hugtakið forysta og hverjir sinna henni í skólanum?

Fyrst var unnið úr matstækinu. Reiknaður var fjöldi svara við hverri staðhæfingu og reiknað hlutfall. Dá voru athugasemdir listaðar upp og flokkaðar eftir áherslum. Litið var til peirra áherslna í viðtölunum og sérstaklega spurt um atriði sem teymin mátu mjög ólíkt. Sú var raunin um staðhæfingar eins og miðlun eigin reynslu til samstarfsfólks og um styðjandi aðstceður, skuldbindingu við próunarstarf, handleiðslu og leiðsögn í starfi. Viðtölin voru hljóðrituð og afrituð orðrétt með sampykki viðmælenda. Síðan voru pau lesin yfir, flokkuð og skoðuð út frá lykilhugtökum rannsóknarinnar (Cohen, Manion og Morrison, 2000). Í gögnunum mátti greina skýra tengingu við lykilhugtökin lærdómssamfélag, teymisvinnu/samstarf og forystu en auk pess mátti greina endurtekin stef um kosti og galla aldursblöndunar, vinnuálag og faglega einangrun teyma sem túlka má sem áskoranir.

Vísað verður til ummæla í rýnihópaviðtölum í bekkjarteymum og kennarateymi. Til að forðast rekjanleika voru teymin af handahófi tengd við bókstafina T, E, Y, M, I og N sem saman mynda orðið TEYMIN. Skólastjórnendateymið fékk ekki bókstafsheiti.

\section{Siðferðileg mál og takmarkanir}

Dó hér sé um eftirfylgnirannsókn að ræða er hún umfangsminni en upphaflega rannsóknin, með tilliti til bæði tíma og aðferða. Hún var unnin á einu skólaári og er ekki starfendarannsókn. Hún nær einkum til stjórnenda og kennara í teymum og gefur pví ekki eins heildstæða mynd af stöðu lærdómssamfélags í skólanum og sú fyrri. Hún gefur hins vegar vísbendingar um einkenni og áherslur teymisvinnunnar á tilteknum tíma og um helstu áskoranir sem skólinn stendur frammi fyrir í sambandi við forystu og teymisvinnu.

Vegna mikilla mannabreytinga var tiltölulega stór hluti kennara nýráđinn til skólans, margir reynslulitlir og tæplega nægilega vel inni í málum skólans pegar rannsóknin var unnin.

\section{Niðurstöður}

Skólahúsnæðið hefur stækkað frá pví árið 2012 en skólinn er nú fullbyggður. Skólinn er pó enn teymisskóli og eru teymin í skólanum samsett á svipaðan hátt og árið 2012. Orðið hafa skólastjóraskipti og einn deildarstjóri hefur bæst við stjórnendateymið. Frá 2015 hefur árlega orðið breyting á samsetningu stjórnendateymisins. Miklar mannabreytingar hafa verið í skólanum og samsetning teyma og nemendahópa breytist ört. Pað veldur miklu álagi á allt starfsfólk. Nemendafjöldinn er 380 og kennarar 29. Prír kennarar af peim 11 sem upphaflega hófu störf við skólann eru enn starfandi. 
Stjórnendur telja kennsluna í skólanum einkennast af samkennslu með einhverjum undantekningum pó. Ágreiningur er um greinakennslu í aldursskiptum hópum og samkennslu 1 aldursblönduðum hópum. Stjórnendur telja nauðsynlegt að finna lausn á peim ágreiningi með aðstoð utanaðkomandi aðila. Peir segja samkennslu árganga reynast mörgum kennurum erfiða auk pess sem greinilegt sé að sum teymin séu sjálfbærari en önnur og að tilhneiging sé til faglegrar einangrunar milli teyma. Deir sögðu: „Kennarar eru samviskusamir og vilja skila nemendum færum út í samfélagið. Deir eru hræddir um að samkennslan verðfelli nám peirra“. Hugtakið lærdómssamfélag er að mati stjórnenda flestum kunnugt í skólanum en lítið notað. Að peirra mati eru hugtökin teymisvinna og teymiskennsla hins vegar öllum töm pó ekki sé fyllilegur samhljómur um túlkun og útfærslur. Stjórnendur segja kennara meðvitaða um að peir hafi umboð til að taka forystu en að peir telji sig ekki hafa tíma og svigrúm til að sinna henni innan vinnutímarammans. Stjórnendur lýsa áhyggjum af miklum mannabreytingum og uppstokkun teyma og einn peirra sagði:

Hér er teymisvinnumenning en við erum að kljást við mikla starfsmannaveltu og ráða inn nýtt fólk. Баð kemur fyrir að teymismenning hrynur pegar nýir bætast í teymin. Áskorunin er að halda dampinum inni í teymunum með öllu pessu nýja fólki sem er að detta inn. Par sem teymisvinnan hefur gengið vel höfum við farið virkilega á flug.

Annar sagði:

Á hverju ári eru fagleg og persónuleg átök í einhverjum teymum. Með formlegri aðkomu stjórnenda að trúnaðarfundum hefur pað breyst mikið og persónulegum átökum hefur fækkað. Reynt er að hafa allt meira á yfirborðinu, á faglegum nótum, og leita leiða til að leysa mál í sameiningu.

Hér á eftir verður gerð grein fyrir niðurstöðunum út frá lykilhugtökunum lærdómssamfélag, teymisvinna og forysta og peim áskorunum sem endurspegluðust skýrt í öllum gögnunum, pað er aldursblöndun, vinnuálag, mannabreytingar og fagleg einangrun teyma.

\section{Lærdómssamfélag}

Ljóst var á viðmælendum að hugtakið lærdómssamfélag er sjaldan notað í skólanum og pví ekki mikið haldið á lofti nema hjá einstaka aðilum og pá helst ,í sparifötunum, á málstofum og 1 formlegu próunarstarfi með utanaðkomandi aðilum“ (teymi I). Svo virtist sem pað væri helst skólastjóri sem tæki sér hugtakið í munn í daglegu skólastarfi. Eins kom fram að pað væri notað $i$ atvinnuviðtölum. Nokkrir höfðu ekki heyrt hugtakið notað og einn sagðist ekki vera viss um að hann skildi alveg hugmyndafræðina að baki pví. Annar sagði:

Баð poppar upp svona annað slagið. Detta var miklu meira notað hérna fyrst pegar við vorum að byrja. Pá var unnið í pví að samræma skilning á pví og rýnt í merkingu pess. Birtingarmynd pess er meira notuð núna, p.e. teymisvinna og teymiskennsla (teymi Y).

Svipaðar áherslur mátti heyra víðar og pá einnig að nám kennaranna ykist með samkennslu (teymi E). Í teymi $\mathrm{N}$ var ríkjandi sú túlkun að skýr verkaskipting í teymum væri mikilvægasta birtingarmyndin.

Niðurstöður matstækis um lærdómssamfélag gefa til kynna að sameiginleg gildi og sýn séu helsti styrkleiki skólans en $91 \%$ svarenda var sammála eða mjög sammála peim áherslupætti og 6\% ósammála. Eina staðhæfingin sem öll teymin voru mjög sammála um var sú að lögð væri áhersla á heildstæða sýn á nám nemenda. Mesta breiddin í svörunum var í páttum er lúta að styðjandi aðstæðum og innra skipulagi, sem var veikasti hlekkurinn í skólanum að mati teymanna. 35\% svarenda voru ósammála eða mjög ósammála peim áherslupætti og 64\% sammála eða mjög sammála (sjá töflu 5). Fimm teymi voru ósammála eða mjög ósammála peim undirlið í staðhæfingunni 
að dagskipulag í skólanum styddi við tækifæri starfsfólks til að læra hvert af öðru og einnig voru fimm teymi ósammála eða mjög ósammála pví að skólapjónusta og aðrir sérfræðingar styddu við starfspróun og nám starfsfólks í skólanum.

Tafla 5. Niðurstöður úr matstæki (8 teymi)

\begin{tabular}{lccccc}
\hline Áherslupættir - fjöldi undirliða & $\begin{array}{c}\text { Mjög } \\
\text { ósammála } \\
\text { \% }\end{array}$ & $\begin{array}{c}\text { Ósam- } \\
\text { mála } \\
\text { \% }\end{array}$ & $\begin{array}{c}\text { Sam- } \\
\text { mála } \\
\%\end{array}$ & $\begin{array}{c}\text { Mjög } \\
\text { sammála } \\
\text { \% }\end{array}$ & $\begin{array}{c}\text { Svöruðu } \\
\text { ekki } \\
\%\end{array}$ \\
\hline Dreifð og styðjandi forysta (11) & 3 & 15 & 55 & 26 & 1 \\
Sameiginleg gildi og sýn (9) & & 6 & 38 & 53 & 3 \\
Sameiginlegt nám og starfspróun (10) & & 14 & 32 & 54 & \\
Miðlun eigin starfsreynslu til & 5 & 16 & 36 & 43 & \\
samstarfsfólks (7) & & & & & \\
Styðjandi aðstæður - samskipti (5) & 5 & 10 & 40 & 43 & 2 \\
Styðjandi aðstæður-innra skipulag (10) & 11 & 24 & 41 & 23 & 1 \\
\hline
\end{tabular}

Eins og sjá má í töflu 5 eru 79\% svarenda sammála eða mjög sammála áherslupættinum um miðlun eigin starfsreynslu til samstarfsfólks en $21 \%$ er ósammála. Undir peim áherslupætti eru fjögur teymi (helmingur) ósammála eða mjög ósammála peim undirlið að starfsfólk hafi tækifæri til að fylgjast hvert með öðru að störfum og piggja endurgjöf frá jafningjum, og fjögur teymi eru ósammála pví að starfsfólk fái handleiðslu og leiðsögn í starfi.

\section{Teymisvinna og teymiskennsla}

Teymi eru einkennandi og litið er á pau sem burðarstólpa í skólastarfinu. Viðmælendur gerðu skýran greinarmun á teymisvinnu og teymiskennslu. Deir sögðu teymisvinnu vera samstarf við undirbúning og mat utan kennslu og teymiskennslu snúast um samstarfí kennslunni. Mismunandi var pó hvernig samstarf var skilgreint 1 teymunum og hvað fólst í samstarfinu. Einn viðmælandi sagði: „Баð eru búnir að vera um 300 fundir um akkúrat pað“ (teymi T). Sum teymin lögðu áherslu á samvinnu og samkennslu í nemendahópnum meðan önnur töldu samvinnuna felast í verkaskiptingu eftir námsgreinum og pemum. Teymin eru ólík og hafa próast á mismunandi hátt. Nokkur teymi eru mjög sterk og geta fallið undir skilgreininguna námsteymi meðan önnur eru styttra á veg komin.

Viðmælendum í teymum var tíðrætt um að peir vissu lítið um hvað gert væri í öðrum teymum. Teymin voru upptekin í sínu og fundu sér ekki tíma til að kynna sér starfið í öðrum teymum. Eitt teymið sagði breytingu hafa orðið á skólanum á undanförnum árum og að teymin hefðu einangrast. Dar kom fram:

Við vitum lítið hvað önnur teymi eru að gera. Degar húsnæðið stækkaði varð samstarf milli teyma torveldara. Teymi hafa líka mismunandi kaffitíma pannig að sum hittast lítið... pegar húsnæðið stækkaði slitnaði skólinn í sundur og við misstum nándina (teymi I).

Talið var brýnt að bæta úr bessu og bent á að fyrir nokkrum árum hefði verið haldið innanhússping par sem teymin kynntu helstu áherslur hjá sér og í kjölfarið var lögð áhersla á að fólk færi markvisst í heimsókn í önnur teymi. Рað hafði svo fjarað undan pví og ekkert slíkt ping hafði verið haldið síðustu árin. Samhljómur var um að vinna pyrfti markvisst í pví að brúa bilið milli teyma og einn aðili sagði: „Petta er kannski helsti veikleiki skólans, petta gap á milli teyma. Fyrsta árið mitt fór ég markvisst rúntinn á milli teyma og lærði heilmikið. Svo varð ég svo upptekin í mínu“" (teymi E). 


\section{Stigskipting teymisvinnu}

Minnihluti aðila í teymum pekkti til stigskiptingar teymisvinnu (tafla 1) sem lögð var til grundvallar í próun teymisvinnu 2012. Margir töldu sig hafa purft kynningu og fræðslu um mismunandi stig teymisvinnu og stuðning við að uppfylla skilyrðin (teymi E og M). Í sumum teymum könnuðust einhverjir við stigskiptinguna en sögðu ekki stutt við hana markvisst í skólanum (teymi Y og N). Teymi I taldi sig hafa próast sem teymi í gegnum árin:

Баð kannski sjálfkrafa reyndi meira á okkur sem kennara eftir að starfsteymin stækkuðu. раð er erfiðara að ræða ágreiningsmál og annað í svona stórum hópi og skilja pað eftir pegar maður kemur út af fundi en við höfum mismunandi styrkleika, bætum hvert annað upp og höfum ótrúlegan styrk hvert af öðru og virkum meira sem lærdómssamfélag.

Eitt teymið (N) er mannað mörgum reynslulitlum og/eða nýjum kennurum. Aðilar í teyminu töldu sig upplifa samkeppni í skólastarfinu, að fólk vildi ekki deila með sér heldur halda í sitt og vera „,besti kennarinn“. Deir töldu að pegar skólinn stækkaði hefði orðið sprenging og að sú menning sem hafði próast áður hefði purrkast út. Deir töldu skorta á stuðning og leiðsögn stjórnenda og utanaðkomandi aðila um hvernig teymin ættu að vinna. Баð kom pó fram hjá peim að skólastjórnendur hefðu leitað til utanaðkomandi aðila um aðstoð við uppbyggingu teymisvinnunnar en hún hefði ekki dugað til. Deir sögðu: „Við erum eiginlega ekki teymi. Við gætum næstum verið sóló á bekk. Við erum að kynnast. Við erum mjög mikið að sligast undan fjölda teymisaðila og nemendahópnum. Við höfum varla haft tíma né orku í að tala um kennslufræðilegu hlutina“.

Dað kom skýrt fram hjá viðmælendum að brýn pörf væri á auknum hagnýtum stuðningi við að próa teymisvinnu í skólanum frá einhverjum sem kynni og hefði reynslu af slíkri vinnu. bað væri hægt að lesa fjöldann allan af fræðigreinum án pess að fá upplýsingar um hvernig ætti að gera hlutina. Einn sagði:

Skólinn ætlar að standa fyrir petta en við fórum af stað með ekkert í höndunum. Dað er erfitt að byrja með eitthvað sem enginn kann, enginn hefur reynt og enginn skilur.Við höfum oft byrjað upp á nýtt. Đað var ofsalega gaman í upphafi en svo bara keyrir maður á vegg pegar verkefnin eru endalaus (teymi $\mathrm{Y}$ )

\section{Áherslur teymisfunda}

Pegar spurt var um prískipta fundi teyma sem höfðu próast 2012, um kennsluáætlanir, nemendamál og um trúnaðarmál kennara, kom fram að sú áhersla er enn til staðar, en útfærslan er aðeins önnur. Nú halda fulltrúar stjórnendateymisins utan um fundi um nemendamál og trúnaðarmál með teymum. Stjórnendur funda um pessi mál með hverju teymi vikulega. Hins vegar er teymunum sjálfum ætlað að stýra fundi og vinnu um kennsluáætlanir og gert er ráð fyrir tíma í pað í vinnuskipulagi. Detta fyrirkomulag hefur að mati flestra teyma gefið góða raun. Meirihluti teyma telur sig vel ráða við trúnaðarhlutann með pessum hætti og kennarar segjast geta gagnrýnt hver annan og verið ósammála á kurteisan hátt. Aðilar eins teymis telja sig hafa orðið „,smurðari““ í teymisvinnu með pessum hætti. Einn viðmælandinn sem hefur starfað lengi við skólann sagði: „Ég hef ekki lent í krísu í teymi síðan í upphafi. Detta er orðið okkur tamara. Vinnurammi með skólastjórnendum er orðinn skýrari og heldur okkur við efnið“" (Teymi I).

Teymi $\mathrm{N}$ taldi pó fundina með stjórnanda ekki nægilega skilvirka og of tímafreka. Dað væri óparfi að hafa pá vikulega. Eitt teymi sagðist ekki hafa haft svigrúm í langan tíma til að hafa fundi um kennsluáætlun og skipulag pví pað væri svo mikið um veikindi og forföll sem pyrfti að bregðast við. Dar var talað um nauðsyn pess að setja viðmið um hvenær ætti að kalla inn í forföll. Dað væri komið út í algjörar öfgar (T). 


\section{Samsetning teyma}

Í öllum viðtölunum komu upp vangaveltur og áhyggjur af síbreytilegri samsetningu teyma sem á sér einkum stað vegna aldursblöndunar og mannabreytinga. Stefnan frá upphafi hefur verið sú í skólanum að pegar nemendur færast upp um árgang og í nýjan samkennsluhóp fylgir einn kennari með til að viðhalda stöðugleika og skapa öryggi fyrir nemendur. Pegar mannabreytingar og nýráðningar bætast við veldur petta að margra mati óstöðugleika og álagi í teymum. Рað fer mikill tími í að tala sig saman í nýju teymi og pegar sú staða kemur upp á hverju hausti verður ekki mikil próun í teyminu. Teymi Y taldi pað vera einn mesta álagspunktinn í skólastarfinu pegar nýr aðili kæmi í teymi. Баð krefðist pess að tekin væri forysta um að leiðbeina honum og styðja hann í störfum par. Í teymi E, sem er mannað mörgum nýjum aðilum, virtist petta pó ekki vera vandamál en par kom eftirfarandi fram:

Рað er með ólíkindum hvað maður er fljótur að, - mér finnst teymisvinnan alveg frábær, alveg frábær - hvað maður er fljótur að treysta.Við erum byrjuð á traustvinnunni, hvaða væntingar við höfum til teymisins. Ég held við séum dálítið góð í pessu.

Dess var pó getið að vissulega væru dæmi um að fólk næði ekki saman en að petta snerist mikið um viðhorf. Deir sögðust vera jákvæðir og vilja láta petta ganga vel.

\section{Aldursblöndun}

Stjórnendur eru hlynntir stefnunni um aldursblöndun í skólanum, telja hana geta stuðlað að fjölbreyttari starfsháttum en ella og aukinni lausnaleit. Viðhorf teyma til aldursblöndunar er hins vegar misjafnt og nokkur teymi telja að pað vanti sterkari fagleg rök fyrir henni. Pau sjónarmið komu fram að stefnan hefði betur átt við á upphafsárum skólans pegar nemendur voru færri og að petta væri heppilegra í litlum skólum með fáum nemendum í árgangi par sem erfitt gæti reynst að finna félaga. Nú eru nemendahópar stórir í skólanum svo sá vandi er ekki fyrir hendi að mati viðmælenda. Bent var á að getubil nemenda í tveggja til priggja árganga hópi væri afar breitt. Einnig væru stöðugar breytingar á hverju ári pví nemendur færðust milli stiga. Detta kallar á nýja kennara og félaga og getur valdið streitu hjá nemendum og jafnvel kennurum. Með pessu verða mörg uppbrot sem draga úr samfellu í námi. Рað eru alltaf nýir umsjónarhópar, bekkjardeildin breytist og stöðug valdabarátta á sér stað. Reynt er að tengja saman nemendur á mismunandi aldri en svo eru peir aðskildir að ári. Ætla má að um pað bil priðjungi kennara finnist snúið að hafa aldursblandaða hópa í petta stórum skóla og telji að verið sé að flækja skólastarfið með pví móti.

Tvö teymi ( $\mathrm{N}$ og T) sögðust lítið aldursblanda nemendum í kennslu pó peim væri ætlað að gera pað og töldu aldursblöndunina ekki eiga við í skólanum núna vegna stærðar hans. Eitt teymið (I) taldi sig merkja vanlíðan og óöryggi hjá nemendum vegna aldursblöndunar í stórum nemendahópum. Aldursblöndunin var talin skapa óstöðugleika í starfinu pví margt í skipulagi skólakerfisins væri ákveðinn fasti fyrir hvern árgang, svo sem lykilhæfni í aðalnámskrá og samræmd próf. Auk pess væru ýmsar hefðir í bæjarfélaginu tengdar árgöngum, svo sem í tengslum við skólabúðir og ípróttaviðburði. Dessir pættir röskuðu starfi í sampættri kennslu.

\section{Forysta}

Stjórnendur sögðu kennara taka forystu, og pá helst í sínum teymum, en að pað vantaði forystu milli teyma, að gera starfið sýnilegt og eiga umræðu um pað í skólanum í heild og út á við. Deir sögðu teymin ekki taka forystu á sama hátt og áður og að flæði á milli teyma væri lítið. Deir sögðust einnig greina vilja hjá kennurum skólans um að skólinn væri í forystu á sínu sviði en að peir vildu frekar að forystan væri hjá stjórnendum en peim sjálfum. Pá töldu peir kjarasamninga kennara hafa aukið neikvæða umræðu um forystu. 
Stjórnendur sögðust merkja preytu hjá fólki við að draga vagninn í síbreytilegum teymum. Detta kom einnig fram hjá fulltrúa Y-teymisins en hann sagði:

pað er ekki nógu mikið metið innan skólans ef maður er í löskuðu teymi og pað er einn, tveir eða prír sem sjá um að láta allt rúlla og taka forystu. Dað er ekki metið.

Umræðan í teymunum gaf til kynna að skólastjórnendur minntu kennara reglulega á að peir væru sérfræðingar og að peir hvettu pá til að taka forystu um mál í skólanum (N og Y). Einn kennari sagði: ,Já, maður er spurður hvort maður vilji eitthvað en kjaramálin draga úr áhuganum. Maður fær ekkert auka fyrir neitt og pað er ekkert svigrúm“ (E). Annar í sama teymi sagði: „Maður veit um færa aðila hér innanhúss sem hafa brennandi áhuga á einhverju en peir gefast upp ef ekki er gefinn neinn afsláttur á móti“.

Í M-teyminu snerist umræðan um forystu um skort á eftirfylgni og aðhaldi frá stjórnendum. Deim fannst tilhneiging til að umræðan um forystu milli stjórnenda og kennara gufaði upp og yrði ekki að neinu. Deir töldu fólk hafa áhuga og vilja til að taka forystu en svo væri ekki nægilega vel stutt við bakið á pví og pað hvatt áfram til pess. Að peirra mati voru stjórnendur ekki nægilega sýnilegir í kennslustundum og höfðu par af leiðandi ekki pá innsýn í kennsluna sem nauðsynleg væri til að geta veitt endurgjöf um hana.

Ein birtingarmynd forystuhugsunar í skólanum er að fólk er virkjað í nefndir og sinnir par ákveðinni forystu (I). Баð kom einnig fram í teymi I að starfsumhverfi kennara hefði breyst mikið á skömmum tíma, að starfið væri umfangsmeira en áður og að kennarar pyrftu að hafa marga bolta á lofti samtímis. Teymisaðilar töldu sig margir hverjir vera mikla fagaðila og vita hvað pyrfti að gera en að ekki ynnist tími til pess prátt fyrir stífa forgangsröðun. Deir sögðu kennara preytta og að kjarabaráttan hefði farið illa með fólk. Einu teyminu (T) var tíðrætt um neikvæða forystu hjá kennurum og að hún kæmi í veg fyrir uppbyggjandi og lausnamiðaða hugsun, starfsemi og próun. Deir sögðu skólann hafa misst marga góða kennara í fyrra út af pessu og út af kjaramálaumræðu.

Í viðtölum kom fram að skólastjórnendur hældu starfffólki gjarnan og sýndu ábyrgð með jákvæðri pátttöku á teymisfundum.

\section{Umræða}

Í pessari rannsókn var leitað svara við pví hvað einkennir teymisvinnu og forystu í skólanum fimm árum eftir að innleiðingarferli lærdómssamfélags lauk 2012 og hverjar væru helstu áskoranirnar.

Í árslok 2012 var teymisvinna allsráðandi í skólanum og lögð var áhersla á að innri umgjörð teymisvinnunnar styddi við faglegt starf teymanna. Teymin héldu prjá fundi á viku; einn um kennsluáæetlanir, einn um nemendamál og einn um trúnaðarmál kennara, og peir tóku forystu um mál innan skólans með stjórnendateymi. Teymin voru pó vissulega misjöfn og sum voru faglegri en önnur. Tvö teymi í skólanum fóru nærri pví að falla undir skilgreiningu KrøllSchwarz (2004) um námsteymi sem sýndi sig meðal annars í langvarandi og skuldbindandi samvinnu og markmiðum varðandi framvindu nemenda í námi og starfspróun kennara í teymi. Nokkur teymi voru á 3. stigi en par var skuldbinding um samvinnu og stuðning ekki eins afgerandi. Skólastjórnendur heimsóttu kennslustundir reglulega og spurðu kennara gagnrýninna spurninga um kennsluna, gáfu endurgjöf og leituðu lausna með kennurum. Dað hefur sýnt sig skipta miklu máli í forystu um að próa skólastarf og efla fagmennsku kennara (Börkur Hansen og Steinunn Helga Lárusdóttir, 2014; Heikkinen o.fl., 2012). Stjórnendateymið hafði verið óbreytt frá upphafi.

Skólinn er enn teymisskóli og á teymisfundum er lögð áhersla á að ræða og vinna með trúnaðarmál auk pess að byggja upp traust, ræða kennsluáætlanir og nemendamál. Viðmælendur eru almennt 
ánægðir með að lögð sé áhersla á teymisvinnu og finnst hugmyndafræði lærdómssamfélags svífa yfir vötnum pó hugtakið sjálft sé ekki mikið notað. Litið er á teymiskennsluna sem birtingarmynd lærdómsamfélags. Teymin eru hins vegar mjög mislangt á veg komin í teymisvinnunni miðað við viðmið Krøll-Schwarz (2004). Sum eru vel faglega starfhæf meðan önnur pyrftu formlega leiðsögn og flæði milli teyma er afar lítið. Viðleitni er til faglegrar og dreifðrar forystu í skólanum en kjaramál, tímaskortur, óskilvirkt skipulag og eftirfylgni stjórnenda hamla bví að kennarar taki forystu nema að takmörkuðu leyti. Miklar mannabreytingar og óstöðugleiki í teymum, samkennsla aldursblandaðra nemendahópa, kjarasamningar, veikindi og forföll valda miklu vinnuálagi hjá kennurum.

Hér verður nánar varpað ljósi á pá meginpræði sem greina mátti í niðurstöðum rannsóknarinnar, gefa mynd af stöðunni í skólanum og helstu áskorunum. Dað er annars vegar teymisvinna, fagleg einangrun teyma og skortur á forystu og hins vegar vinnuálag, nýliðun og skortur á formlegri leiðsögn. Ýmsir angar í innra starfi skólans bera pess merki að vilji sé til faglegra vinnubragða og starfspróunar (áhersla á nám nemenda, sameiginleg gildi og sýn) en aðrir pættir hamla pví að hægt sé að fullyrða að skólinn uppfylli skilyrði lærdómssamfélags eins og pað er skilgreint hér.

\section{Teymisvinna, fagleg einangrun og skortur á forystu í námi}

Skólinn er enn teymisskóli og teymisvinnan er talin vera birtingarmynd lærdómssamfélags í skólanum. Teymi eru grunneining í lærdómssamfélagi (Prytula, 2012) og purfa að uppfylla ákveðin skilyrði um gagnvirkt samstarf og starfspróun til að svo sé. Í mörgum teymum er að finna gróskumikið og faglegt starf og jákvæðni ríkti í garð teymisstarfsins par sem talin var eiga sér stað gagnrýnin og lausnamiðuð umræða. Dessar niðurstöður eru í samræmi við niðurstöður starfsháttarannsóknar um að kennarar í teymum eigi opnar og gagnrýnar umræður um skólamál (Gerður G. Óskarsdóttir, 2014). Heyra mátti dæmi um endurgjöf kennara í milli í pessari rannsókn en hún virtist pó ekki alltaf markviss og ekki allsráđandi. Kennarar hér virðast pví ekki frábrugðnir öðrum íslenskum kennurum hvað petta varðar en lítil hefð virðist vera fyrir pví hjá peim að gefa hver öðrum uppbyggjandi endurgjöf eða leiðsögn um kennslu (Doppenberg o.fl., 2012; Ragnar Ólafsson o.fl., 2012).

Pó að viðmið Krøll-Schwarz (2004) séu nú ekki almennt pekkt og höfð til hliðsjónar við skilgreiningu á stöðu teyma í skólanum virðist sú hugsun sem par birtist engu að síður hafa skilað sér til meirihluta kennara og teyma og vera hluti af stofnanaskilningi á teymiskennslu. Allflestir viðmælendur sáu stigsmun á milli teymisvinnu og teymiskennslu par sem síðarnefnda hugtakið var talið flóknara og eftirsóknarverðara og snúa bæði að nemendum og starfsfólki, kennslu og starfspróun. Túlka má niðurstöður pannig að kennarar í um helmingi teymanna leitist við að efla fagmennsku sína og stuðla að starfspróun með til að auka námsárangur nemenda og skapa heildræna sýn á nám nemenda. Að pessu leyti uppfylla peir skilyrði lærdómssamfélags að hluta til eins og pau eru listuð upp í matstæki um lærdómssamfélag hjá Olivier og Hipp (2010).

Greina mátti mismunandi túlkun á hugtakinu samvinna í teymunum í samræmi við umfjöllun Jackson og Burch um samrád og samstarf (2016). Í einu teyminu var samvinnan talin felast í pví að skipta með sér verkum (e. cooperation) meðan skynja mátti annars konar samstarf sem einkenndist af trausti, ígrundun og samvinnu (e. collaboration) hjá öðrum teymum og fellur pá undir viðmið um námsteymi á fjórða stigi hjá Krøll-Schwarz (2004). Hjá peim teymum mátti sjá að kennarar unnu saman á markvissan hátt við að próa starf sitt með nemendum eins og Fagráð um símenntun og starfspróun kennara og skólastjórnenda (2016) leggur áherslu á í skilgreiningu sinni og talinn er nauðsynlegur páttur til starfspróunar (Anna Kristín Sigurðardóttir, 2010; Darling-Hammond og Richardson, 2009). Starfshættir og viðhorf í tveimur teymum gáfu ekki tækifæri til samvinnu og náms kennara á starfsvettvangi með sama hætti og í hinum teymunum.

Ekki er sama skuldbinding hjá kennurum teyma nú og 2012 um að fylgja skipulagi skólans um innihald teymisfunda og dæmi voru um að teymi ynnu á skjön við pað. Ramminn um 
teymisvinnuna og dagsskipulag sem gegndi pví mikilvæga hlutverki að skapa aðstæður sem styðja við samstarf og starfspróun gera pað ekki með sama hætti nú. Petta gefur til kynna að skortur sé á sameiginlegri sýn og skuldbindingu um vinnubrögð og áherslur og að innri aðstæður styðji ekki nægilega vel við kennara eins og menning lærdómssamfélags gerir (Birna Svanbjörnsdóttir, 2015; Birna Svanbjörnsdóttir o.fl., 2016; Hargreaves og Fullan, 2012; Roy og Hord, 2006). Ætla má að pessi breyting hafi áhrif á pá staðreynd að teymin taka nú ekki á sama hátt forystu um mál innan skólans, mynda pví ekki pá heildarumgjörð um starfið og styðja ekki við starfspróun og breytingastarf eins og pörf er á og væntingar voru um að próa. Hugmyndafræðin á bak við teymisvinnuskóla er að samstarfið, samstaðan og krafturinn í starfi í teymunum leiði framvindu og próun í skólanum eins og raunin varð í fyrri rannsókninni (Birna Svanbjörnsdóttir, 2015) og einnig mátti sjá í rannsókn Blossing o.fl. (2015) í norskum teymisskólum. Pá var flæði milli teyma og pau voru ekki einangruð hvert frá öðru. Tiltölulega fáir kennarar tóku forystu og báru fyrir sig vinnuálag og litla umbun. Spurning er hvort aukin pekking og fræðsla um forystu myndi breyta pessari afstöðu eins og sjá mátti hjá leiðtogum Byrjendalæsis en peir tóku gjarnan forystu og fagmennska peirra jókst í kjölfar formlegar menntunar í pví sambandi. Sú hefur einnig orðið raunin með námsleiðina um kennaraforystu í Ontario (Lieberman o.fl., 2017; Sigríður Margrét Sigurðardóttir o.fl., 2017).

Stjórnendur eru vel meðvitaðir um stöðu teyma í skólanum og leggja sig fram um að skapa aðstæður fyrir samstarf og próun faglegra vinnubragða í skólanum. Deir styðja teymisvinnuna með pví að taka pátt í vikulegum fundum með teymum um trúnaðarmál og leita markvisst álits og stuðnings utanaðkomandi fagaðila á álitamálum. Peir virðast pó ekki pekkja nægilega vel til starfa kennara í kennslu og eiga ekki markvissa og reglulega umræðu við pá um kennslu, nám og leiðir til umbóta. Petta eru svipaðar niðurstöður og fram hafa komið í nýlegum íslenskum rannsóknum sem sýna að skólastjórar sinna vel pví hlutverki að móta stefnu og mynda samstöðu um að próa ákveðið starf en sýna minni forystu í páttum sem tengjast kennslu og námi (Börkur Hansen og Steinunn Helga Lárusdóttir, 2014; Sigríður Margrét Sigurðardóttir o.fl., 2017).

\section{Vinnuálag, nýliðun og skortur á leiðsögn í starfi}

Vinnuálag er síendurtekið stefí niðurstöðunum og má að miklu leyti rekja pað til skipulags innri pátta í skólastarfinu, eins og samkennslu árganga, forystu og mannabreytinga, auk kjarasamninga og skorts á formlegri leiðsögn við teymiskennsluna. Dað er í samræmi við nýlegar niðurstöður úr öðrum gögnum um starfsaðstæður kennara á Íslandi (Birna Sigurjónsdóttir, 2017; Nýliðun og bætt starfsumhverfi grunnskólakennara, 2017; Svandís Ingimundardóttir og Valgerður Ágústsdóttir, 2018). Vinnuálagsumræðan er háværari nú en árið 2012 pegar teymi upplifðu praktíska og faglega vinnu í teymum sem tíma- og orkufreka (Birna Svanbjörnsdóttir o.fl., 2016). Degar mannabreytingar, kjarasamningar og brestir í forystu bætast við hið daglega starf teymanna dregur verulega úr starfsánægju og faglegri skuldbindingu kennara.

Aðra ástæðu vinnuálagsins má rekja til pess að hátt hlutfall nýliða sem starfa við skólann fær ekki formlegan stuðning eða leiðsögn um próun starfshátta og mótun starfskenningar sem talin er nauðsynleg til að efla fagmennsku peirra og starfsproska (Ingersoll, 2012). Peir upplifðu mikla óvissu og óöryggi og fannst ýmis praktísk mál flækjast fyrir sér í kennslunni. Reyndir kennarar upplifðu pað sem aukið vinnuálag að setja nýliða inn í starf teymanna og fannst pað ekki vera sitt hlutverk. Deir kölluðu margir sjálfir eftir leiðsögn við próun teymisvinnu og teymiskennslu. Algengt er að formlegri leiðsögn við nýliða og aðra sé ábótavant í íslenskum skólum. Ef leiðsögn er á annað borð til staðar er hún óformleg og ekki nægilega skilvirk (Börkur Hansen og Steinunn Helga Lárusdóttir, 2014; Hildur Hauksdóttir o.fl., 2018; María Steingrímsdóttir og Guðmundur Engilbertsson, 2018). Heikkinen, Jokinen og Tynjälä (2012) hafa reynslu af nokkurs konar jafningjaleiðsögn í samstarfshópi kennara með mislanga starfsreynslu í finnskum skólum sem skilað hefur góðum árangri og styrkt faglegt starf. Í pví sambandi er mikilvægt að sá eða peir sem hafa forystu um leiðsögnina hafi pekkingu og reynslu í leiðsagnarfræðum. 
Markmiðið með peirri stefnu skólans á upphafsárum hans að kenna nemendum í aldursblönduðum hópum var að tryggja að mismunandi pörfum nemenda væri mætt, pví óhjákvæmilegt væri að koma auga á ólíkar parfir pegar breiddin væri svo mikil (Åheim, 2009). Samstaða var um pessa stefnu til að byrja með (Birna Svanbjörnsdóttir o.fl., 2010) en nú voru komnar upp margar efasemdaraddir um gildi hennar. Kennurum fannst rökstuðningur skólastjórnenda fyrir stefnunni ekki nægilega markviss og settu sjálfir fram rök gegn henni. Andstaða kennara í nokkrum teymum var svo mikil að peir virtu stefnuna að vettugi og kenndu aldursskipt meðan aðrir sýndu meiri skuldbindingu og ábyrgð og leituðu leiða til að framfylgja henni. Parna skortir á sameiginlega sýn og stefnu sem talin er nauðsynleg í lærdómssamfélagi (DuFour og Fullan, 2013). Petta varð til pess að kallaður var saman samstarfshópur til að rýna betur í kjölinn á viðfangsefninu og taka ákvörðun um að finna sátt í málinu. Fenginn var utanaðkomandi aðili til að stýra peirri vinnu.

\section{Lokaorð og helstu áskoranir}

Ekki leikur vafi á pví að teymisvinna er enn við lýði í skólanum fimm árum eftir innleiðingu og próun lærdómssamfélags og er teymiskennslan talin vera birtingarmynd lærdómssamfélags. Almenn ánægja er með pá áherslu en starfið í teymunum er misjafnlega útfært og lítið flæði er milli teyma. Skólastjórnendur sýna skýra forystu með pví að halda utan um einn teymisfund í hverju teymi vikulega og gefur pað til kynna afdráttarlausan vilja peirra til að styðja teymin í teymisvinnunni. Dað má einnig ljóst vera að sú aðgerð styrkir teymin í að byggja upp innri trúnað og traust. Fleiri dæmi eru um að stjórnendur hafi leitað leiða til að styrkja innviði skólans og hafi leitað eftir aðstoð utan frá, svo sem til að bregðast við ágreiningi um aldursblöndun og kalla eftir stuðningi við teymiskennslu. Eins er lögð áhersla á að dagskipulag og stundaskrár gefi tækifæri til samvinnu teyma pó teymi meti aðstæður mismunandi.

Skólastjórnendur purfa pó að takast á við ýmsar áskoranir. Til staðar er ákveðin togstreita milli kennara og stjórnenda um stefnu og sýn skólans og pörf er á formlegri leiðsögn á vettvangi um teymiskennslu, bæði til nýliða og reyndra kennara.

Viðvarandi nýliðun, kennsla í aldursblönduðum hópum, kjarabarátta og áskoranir í forystu stjórnenda og annarra veldur vinnuálagi hjá stórum hópi kennara og ljóst er að pað dregur úr skuldbindingu peirra til að taka forystu. Nýir kennarar pekkja ekki til fræða sem liggja til grundvallar teymisvinnunni og eru óvissir um útfærslu og vinnubrögð. Kallað er eftir auknum tækifærum til samstarfs í skólanum, bæði innan teyma og á milli teyma.

Helstu áskoranirnar sem rannsóknin gefur til kynna eru að:

- Efla purfi forystu almennt og formgera flæði milli teyma,

- skólastjórnendur fari markvisst inn í kennslu og veiti kennurum endurgjöf,

- meðlimir teyma nýti sér tækifærin sem felast í skipulagi skólastarfsins til að læra hver af öðrum og með hver öðrum,

- tryggja að aðili í skólanum hafi sérhæfingu í starfstengdri leiðsögn og taki forystu um að innleiða og próa leiðsagnarmenningu í skólanum.

Jafnvel pó að litið sé á teymi sem grunneiningu lærdómssamfélags og að skilgreina megi skólann sem teymisskóla er ekki par með sagt að fullmótað lærdómssamfélag hafi próast í skólanum enda háleitt og flókið markmið að stefna að með öllum peim páttum sem par falla undir. Með pví að vinna með ofangreinda pætti verður stórt skref tekið í átt að markmiðinu. 


\section{Teamwork and leadership: Manifestation five years after the completion of the induction process of a professional learning community}

From August 2009 to December 2012 a professional learning community was inducted and developed in a new urban primary school. Simultaneously, an action research study was carried out in the school, in cooperation with external parties and the school leaders. The aim of the research was to establish the effects of leadership on professional development and factors which support this leadership. The research was based on leaders' reflections, field observations, interviews and evaluation, and examination of data available at the school. At the end of the research period, results showed that teamwork characterized the work at the school and that teams took on leadership in many ways, together with the school leaders. Many teams could be defined as learning teams characterized by a commitment to collaboration, emphasizing the professional as well as the learning process of their members. This work met with some obstacles but leaders took on their role with resilience, feedback and problem solving as their main resources. Five years later, during the school year of 2017-2018, a follow-up study was carried out at the school, based on focus group interviews with all the teams at the school and an assessment tool for learning communities. The following research questions were posed: What characterizes teamwork and leadership at the school five years after the completion of the induction process of a learning community in 2012? What are the main challenges? Since the original study, the number of pupils at the school has increased at the same time as there have been considerable changes in staff, including a large number of new recruits. Furthermore, a new headmaster has taken over and the team of school leaders has grown. There are now 380 pupils and teachers are 29 at the school. Three of the 11 teachers who were hired when the school was first opened still work there. The school is still characterized by teamwork and its internal structure supports mixed-age teaching and collaboration. Team meetings focus on discussions of, and work on, confidential matters, together with issues regarding trust, teaching plans and student-related issues. The results indicate that the flow of information between teams is limited, as is the involvement and formal support of leaders in teaching. The informants in the study are generally happy with the emphasis on teamwork and believe that the ideology of the learning community is tangible in the school even though the term as such is not used much. Teaching in teams is regarded as a manifestation of a learning community. The study reveals two main trends with regard to the current situation in the school and its main challenges. These are, on the one hand, teamwork, the professional isolation of teams and challenges in leadership, and, on the other, workload, recruitment of new staff and lack of formal mentoring. The teams differ from one another and have developed in various ways. Some of them are quite strong and can be defined as learning teams, while others still have some way to go. Efforts are made at the school towards professional and dispersed leadership but salaries, lack of time and unclear messages from leaders only allow teachers to take on leadership to a limited extent. Constant changes in staff, teaching in mixed-age groups, the fight for improved employment conditions, and challenges to the role of leaders and others increases the pressure on many of the teachers and diminishes their commitment to leadership. School leaders meet once a week with each of the teams. They have also sought external support and advice to solve problems regarding the development of teamwork. However, they take little direct part in teaching and provide limited pedagogical feedback. Teachers are unfamiliar with the science and practice behind the teamwork, and need mentoring. There is a call for formal and professional support in the field, and for opportunities for cooperation in the school, both within teams and between them. The main challenges indicated by the study are: 
- The general strengthening of leadership and the formalisation of flow between teams

- The direct involvement of school leaders in teaching and their provision of feedback to teachers

- Teams' use of opportunities provided by the structure of the schoolwork to work and learn with one another

- Ensuring that someone at the school is specialized in mentoring and leads the induction and development of mentoring in the school.

Even though teams are base units in a PLC and the school is a team school, the teamwork requires further improvement to fulfil the demands for a PLC, which is a high and complicated goal to achieve. Working on the challenges indicated above is a big step towards that goal.

Keywords: professional learning community, teamwork, collaboration, mentoring and leadership

\section{Um höfundinn}

Birna María B. Svanbjörnsdóttir (birnas@unak.is) er lektor við kennaradeild hug- og félagsvísindasviðs Háskólans á Akureyri. Hún lauk kennaraprófi frá Kennaraháskóla Íslands 1988 og starfaði sem grunnskólakennari um árabil. Birna lauk meistaraprófi frá Háskólanum á Akureyri 2005 og doktorsprófi frá Háskóla Íslands 2015. Helstu áherslur í rannsóknum hennar lúta að starfspróun kennara og uppbyggingu og próun faglegs lærdómssamfélags.

\section{About the author}

Birna María B. Svanbjörnsdóttir (birnas@unak.is) is an assistant professor at the Faculty of Education at the University of Akureyri. She graduated as a teacher from Iceland University of Education in 1988 and has a long teaching career in primary schools. Birna completed a Master's degree from the University of Akureyri in 2005 and a Ph.D. from the University of Iceland in 2015. Her main areas of emphasis in research are teacher development and professional learning communities 


\section{Heimildir}

Anna Kristín Sigurðardóttir. (2010). Professional learning community in relation to school effectiveness. Scandinavian Journal of Educational Research, 54(5), 395-412. doi:10.1080/00313831.2010.508904

Åheim, A. (2009). Aldersblanding som idé, prinsipp og metode i nærmiljøskulen. Í K. Melheim (ritstjóri), Narmiljøpedagogikk (bls. 41-53). Oslo: Det Norske Samlaget.

Birna Sigurjónsdóttir. (2017). Starfsaðstæður kennara. Niðurstöður úr rýnihópum kennara í grunnskólum Reykjavíkur um bókun 1 i kjarasamningi. Reykjavík: [Skóla- og frístundasvið].

Birna Svanbjörnsdóttir. (2015). Leadership and teamwork in a new school: Developing a professional learning community (doktorsritgerð). Sótt af http://hdl.handle.net/1946/20818

Birna Svanbjörnsdóttir, Allyson Macdonald og Guðmundur Heiðar Frímannsson. (2010). Að undirbúa nám í nýjum skóla: Áherslupættir stjórnenda og mannaráđningar. Tímarit um menntarannsóknir, 7, 43-59.

Birna Svanbjörnsdóttir, Allyson Macdonald og Guðmundur Heiðar Frímannsson. (2016). Teamwork in establishing a professional learning community in a new Icelandic school. Scandinavian Journal of Educational Research, 60(1), 90-109. doi:10.1080/00313831.2014.996595

Blossing, U., Nyen, T., Söderström, Å. og Hagen Tønder, A. (ritstjórar). (2015). Local drivers for improvement capacity. Six types of school organisation. London: Springer.

Bolam, R., McMahon,A., Stoll, L., Thomas, S. og Wallace, M. (2005). Creating and sustaining professional learning communities. Research Report Number 637. London, England: General Teaching Council for England, Department for Education and Skills.

Börkur Hansen og Steinunn Helga Lárusdóttir. (2014). Stjórnun og skipulag. Í Gerður G. Óskarsdóttir (ritstjóri), Starfshæettir í grunnskólum við upphaf 21. aldar (bls. 87-112). Reykjavík: Háskólaútgáfan.

Coe, R., Waring, M., Hedges, L. og Arthur, J. (ritstjórar). (2017). Research methods \& methodologies in education (2. útgáfa). Los Angeles: Sage.

Cohen, L., Manion, L. og Morrison, K. (2000). Research methods in education (5. útgáfa). London: RoutledgeFalmer.

Darling-Hammond, L. og Richardson, N. (2009). Teacher learning: What matters? Educational Leadership, 66(5), 46-53.

Doppenberg, J. J., Brok, P. J. og Bakx, A.W. (2012). Collaborative teacher learning across foci of collaboration: Perceived activities and outcomes. Teaching and Teacher Education, 28(6), 899-910. doi:10.1016/j.tate.2012.04.007

DuFour, R. og Fullan, M. (2013). Cultures built to last. Systemic PLCs at work. Bloomington: Solution Trees Press.

Fagrád um símenntun og starfspróun kennara. (2016). Skýrsla til mennta- og menningarmálaráðherra. Sótt af https://www. $\mathrm{ki}$.is/component/attachments/download/279

Fullan, M. og Hargreaves, A. (2016). Bringing the profession back in. Call to action. Sótt af http://learningforward.org/docs/ default-source/pdf/BringingProfessionFullanHargreaves2016.pdf

Gerður G. Óskarsdóttir (ritstjóri). (2014). Starfshattir í grunnskólum við upphaf 21. aldar. Reykjavík: Háskólaútgáfan.

Hall, G. og Hord, S. (2011). Patterns, principles and potholes (3. útgáfa). Boston: Pearson.

Hargreaves,A. (2007). Sustainable professional learning communities. Í L. Stoll og K. Seashore Louis (ritstjórar), Professional learning communities. Divergence, depth and dilemmas (bls. 181-195). Maidenhead: Open University Press.

Hargreaves, A. og Fullan, M. (2012). Professional capital:Transforming teaching in every school. New York:Teacher College Press.

Harris, A. (2010). Distributed leadership: Evidence and implications. Í T. Bush, L. Bell og D. Middlewood (ritstjórar), The principles of educational leadership and management (2. útgáfa), (bls. 55-69). London: Sage.

Heikkinen, H., Jokinen, H. og Tynjälä, P. (ritstjórar). (2012). Peer-group mentoring for teacher development. London og New York: Routledge.

Hildur Hauksdóttir, María Steingrímsdóttir og Birna María Svanbjörnsdóttir. (2018). Mótun starfskenningar nýrra framhaldsskólakennara: Hvaða pættir ráða för? Tímarit um uppeldi og menntun, 27(2), bls. 135-154. https://doi.org/10.24270/ tuuom.2018.27.7

Hipp, K. og Huffman, J. (2003). Using assessment tools as frames for dialogue to create and sustain professional learning communities. Í L. Stoll og K. Seashore Louis (ritstjórar), Professional learning communities. Divergence, depth and dilemmas (bls. 119-131). Maidenhead: Open University Press.

Hopkins, D., Stringfield, S., Harris, A., Stoll, L. og Mackay,T. (2014). School and system improvement:A narrative state-ofthe-art review. School Effectiveness and School Improvement, 25(2), 257-281. doi:10.1080/09243453.2014.885452

Ingersoll, R. (2012). Beginning teacher induction: What the data tell us. Phi Delta Kappan, 93(8), 47-57. Sótt af:

Jackson, A. og Burch, J. (2016). School direct, a policy for initial teacher training in England: Plotting a principled pedagogical path through a changing landscape. Professional Development in Education, 42(5), 511-526. 
Krøll-Schwartz, S. (2004). Teamets mappe - inspiration til teamets arbejde og konkrete redskaber i form af kopiark. Frederikshavn: Dafolo Forlag.

Lambert, L. (2003). Leadership redefined: An evocative context for teacher leadership. School Leadership Management, 23(4), 421-430.

Leithwood, K., Anderson, S., Mascall, B. og Strauss, T. (2010). School leaders' influences on student learning: The four paths. Í T. Bush, L. Bell og D. Middlewood (ritstjórar), The principles of educational leadership E management (2. útgáfa), (bls. 13-30). Los Angeles: Sage.

Lieberman, A., Campbell, C. og Yashkina, A. (2017). Teacher learning and leadership. Of, by and for teachers. London og New York: Routledge.

MacBeath, J., Swaffield, S. og Frost, D. (2009). Principled narrative. International Journal of Leadership in Education:Theory and Practice, 12(3), 223-237. doi:10.1080/13603120802684548

María Steingrímsdóttir, Eygló Björnsdóttir og Gretar L. Marinósson. (2017). Leiðsögn kennara í Byrjendalæsi. Í Rúnar Sigpórsson og Gretar L. Marinósson (ritstjórar), Byrjendalosi. Rannsókn á innleiðingu og aðferð (bls. 305-330). Reykjavík: Háskólinn á Akureyri og Háskólaútgáfan.

María Steingrímsdóttir og Guðmundur Engilbertsson. (2018). Mat nýliða á gagnsemi leiðsagnar í starfi kennara. NetlaVeftimarit um uppeldi og menntun. Sótt af http://netla.hi.is/greinar/2018/ryn/03.pdf

Mennta- og menningarmálaráðuneytið. (2014). Hvítbók um umbatur í menntun. Sótt af http://www.menntamalaraduneyti. is/media/frettir/Hvitbik_Umbaetur_i_menntun.pdf

Menntun fyrir alla á Íslandi. Tillögur stýrihóps um fyrstu ađgerðir. (2017, 30. júní). Sótt af http://www.samband.is/media/ skoli-an-adgreiningar/Tillogur-styrihops-um-fyrstu-tillogur.pdf

Nýliðun og bætt starfsumhverfi grunnskólakennara. (2017). Sótt af: https://reykjavik.is/sites/default/files/ymis_skjol/ skjol_utgefid_efni/skrsla.pdf.pdf

Olivier, D. F. og Hipp, K. K. (2010). Assessing and analyzing schools as professional learning communities. Í K. K. Hipp og J. B. Huffman (ritstjórar), Demystifying professional learning communities: School leadership at its best (bls. 29-42). Lanham, MD: Rowman \& Littlefield.

Prytula, M. (2012). Teacher metacognition within the professional learning community. International Education Studies, 5(4), 112-121. doi:10.5539/ies.v5n4p112

Ragnar Ólafsson, Allyson Macdonald og Auður Pálsdóttir. (2012). What matters to Icelandic teachers? Country comparisons based on the TALIS 2008 survey. Rádstefnurit Netlu - Menntakvika 2012. Sótt af http://netla.hi.is/arslok -2012

Ragnhildur Bjarnadóttir. (2015). Leiðsögn. Lykill að starfsmenntun og skólapróun. Reykjavík: Háskólaútgáfan.

Roy, P. og Hord, S. (2006). It's everywhere, but what is it? Professional learning communities. Journal of School Leadership, 16(5), 490-501.

Seashore Louis, K., Leithwood, K., Wahlstrom, K. og Anderson, S. (2010). Learning from leadership: Investigating the links to improved student learning. Final report of research to the Wallace Foundation. [Minnesota]: University of Minnesota.

Sigríður Margrét Sigurðardóttir, María Steingrímsdóttir og Eygló Björnsdóttir. (2017). Forysta í Byrjendalæsi. Í Rúnar Sigpórsson og Gretar L. Marinósson (ritstjórar), Byrjendalasi. Rannsókn á innleiðingu og aðferð (bls. 331-359). Reykjavík: Háskólinn á Akureyri og Háskólaútgáfan.

Spillane, J. (2006). Distributed leadership. San Francisco: Jossey-Bass.

Svandís Ingimundardóttir og Valgerður Ágústsdóttir. (2018). „Á ég að gera pað?“ Skýrsla Skólapings sveitarfélaga 2017. Reykjavík: Samband íslenskra sveitarfélaga.

TALIS. (2013). TALIS 2013: Starfsaðstaður, viðhorf og kennsluhœettir kennara og skólastjóra á Íslandi í alpjóðlegum samanburði. Teaching and Learning International Survey. Alpjóðleg samanburðarrannsókn unnin í samvinnu við OECD fyrir mennta- og menningarmálaráduneytið. [Reykjavík]: Námsmatsstofnun. Sótt af https://mms.is/sites/mms.is/files/talis_skyrsla_2014.pdf

Vescio, V., Ross, D. og Adams, A. (2008). A review of research on the impact of professional learning communities on teaching practice and student learning. Teaching and Teacher Education, 24, 80-91. doi:10.1016/j.tate.2007.01.004

Birna María B. Svanbjörnsdóttir. (2019).

Teymisvinna og forysta: Birtingarmynd fimm árum eftir að innleiðingarferli faglegs lærdómssamfélags lauk

Netla - Veftímarit um uppeldi og menntun. Menntavísindasvið Háskóla Íslands.

Sótt af http://netla.hi.is/greinar/2019/ryn/03

DOI: https://doi.org/10.24270/netla.2019.3 